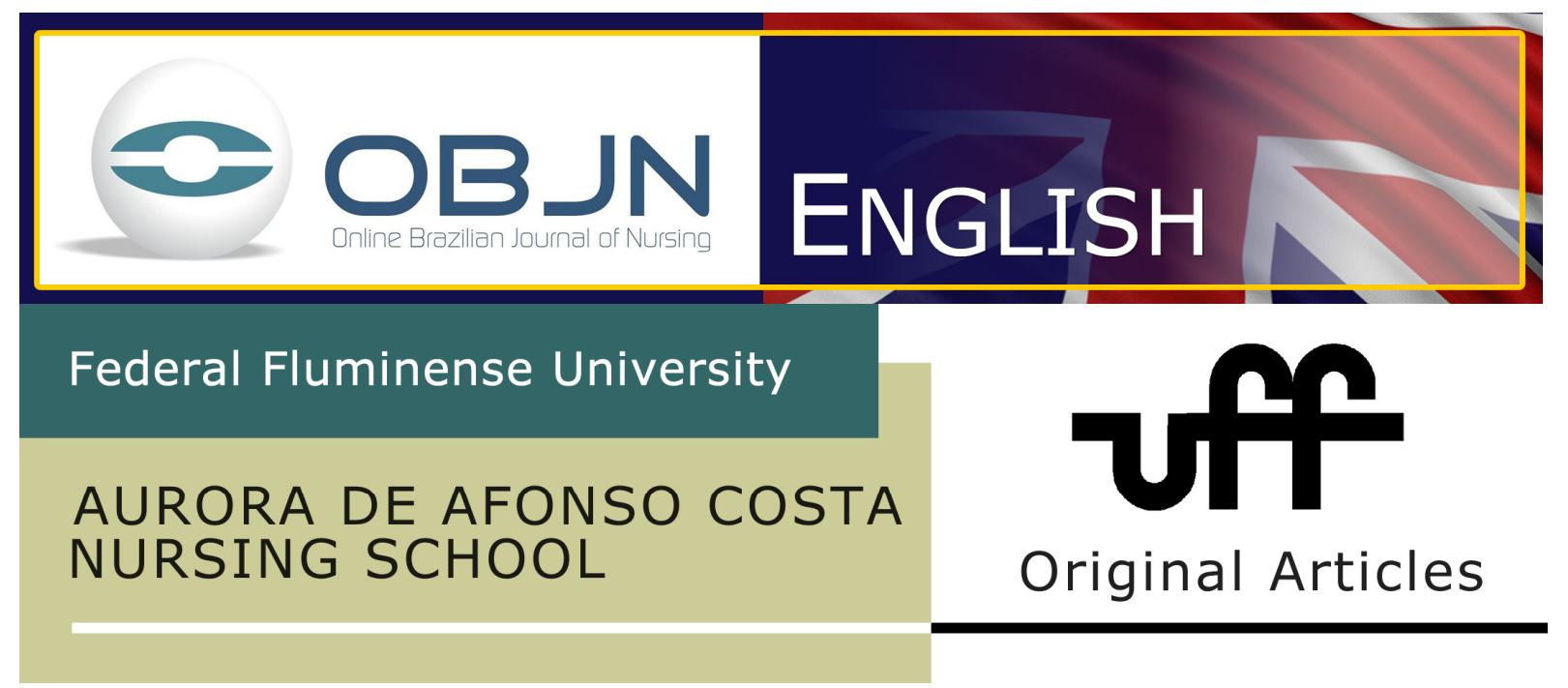

\title{
SUPPORTIVE SOCIAL NETWORKS TO HOMECARE: A DESCRIPTIVE EXPLORATORY STUDY
}

\author{
Jaqueline Dias do Nascimento', Maria Ribeiro Lacerda², Luísa \\ Canestraro Kalinowski ${ }^{3}$, Luciane Fávero ${ }^{4}$
}

1,2,3,4 Parana Federal University

\begin{abstract}
Introduction: Supportive social networks are important to improve people's health conditions and quality of life, particularly regarding home care. Objectives: To identify supportive social networks used by families as well as the ones recommended by health professionals for homecare; to classify them according to the kind of support and relationship offered and approach them. Methodology: Descriptive exploratory qualitative research carried out in 2010 by means of a semi-structured interview with seven families and five users undergoing homecare and ten homecare professionals from a Health Unit. Results: For the families, spiritual support was the most reported, affective one was the least meaningful; the professionals recommended private institutions, NGOs and foundations for material support but most of them reported non-involvement with spiritual support. Families' informal support ultimately came from individuals, which was little reported by the professionals. As for the formal support, families reported religious institutions while professionals cited private organizations, public institutions and advocacy ones. Conclusion: It is necessary for nurse to advise the family to which it is to restructure and divide tasks to assist in homecare through the use of supportive social networks. Articulation between health professionals and local institutions is suggested in order to set up a supportive social network aiming to improve care and foster a positive impact in users' and caregivers' health.
\end{abstract}

Keywords: Social Support, Home Nursing, Nursing. 


\section{INTRODUCTION}

Home care started in the year 1780 , in the United States, with the creation of a service with this destination, bounded with a hospital institution. However only in 1947 in the Montefiore Hospital, in the Bronx, the concept "Home Care", understood at that moment as an extension to hospital treatment, was introduced with an objective to shorten the discharge. In Brazil, the first experience organized in the area happened with the creation of the Medical Home Assistance of Urgency Service (SAMDU, in Portuguese), in $1949^{(1)}$. The necessity of homecare has raised everyday more. It is expected that homecare will definitively establish itself in the $21^{\text {st }}$ century and will have more and more space for the professionals of health, but mostly to nurses and other Nursing professionals ${ }^{(2)}$.

The practice of homecare does not have one and only labor object, and it is formed by both the user, who needs care, and the user's family members ${ }^{(3)}$. The family that has a member who needs constant medical care at home, in many cases, do not have any support or enough resources to treat the member in need according to the necessities, as this person demands, among many factors, financial resources for the treatment ${ }^{(4)}$.

In Brazil, according to the growth of the number of seniors, there is a significant rise of the demand of this parcel of the population and, within this context, homecare becomes a possibility of medical care. Adding to that, it is important to mention that the medical care to the seniors is guaranteed by the Seniors People Statute and by the Brazilian National Guidelines for the Senior People, which both try to safeguard, among others, the right to medical care, including homecare to seniors that need or are impeded to move to the closest clinic or hospital ${ }^{(5,6)}$.

In this sense it is important to be preoccupied with the families, the users and their particularities, the caretakers and with the formation of a supportive social network that is able to help them especially because this network can contribute significantly for the betterment of the health of its participants ${ }^{(4)}$ and safeguards the rights of the assisted people.

Social support can be defined as "any information, spoken or not, or material support 
offered by a group or people that we could have systematic contact and that ends in positive emotional or behavior effects" ${ }^{\prime 7: 325)}$. The social network is a web of relationships that connects diverse individuals that have a certain social bond, and proportionates that the support resources fluctuate among these bonds ${ }^{(8)}$.

From start, to act at home it is important to have sensibility and capacity to mobilize resources available for the caretaking ${ }^{(9)}$, and this may be done through the supportive social networks. While considering that those networks have a great importance for the improvement of general health conditions and quality of life, especially in home caretaking, the health professionals and institutions should be prepared to offer theis support, not only as members of these networks, but also as identifiers of the reources existing in the community, with the purpose to facilitate mainly those with highest economic difficulty ${ }^{(4)}$.

In an integrative review done in 2010 , which objective was to comprehend what were the correlations established between the social networks and homecare, it was perceived in the end of the study that a non-existence of Brazilian studies that aimed to identify the networks developed after the eminence of homecare ${ }^{(10)}$.

So, based on the facts, this study has the following guiding question: "What are the supportive social networks used by families and indicated by the health professionals in homecare?". With this, we objectified to identify those named networks used by the families and those indicated by the health professionals in homecare, so then to classify them according to type of support and relationship offered, and then crisscross them.

This study is relevant once the identification of the supportive social networks existent in a certain community and its classification can contribute to the effectiveness of homecare, as based on this information health professionals can indicate to the user and families the available and more appropriated networks according to the reality and the necessity of each one.

NASCIMENTO JD, LACERDA MR, KALINOWSKI LC, FAVERO L. Supportive social networks to homecare: a descriptive exploratory study. Online braz. J. nurs. (Online); 10(3) set-dez. 2011. 


\section{METHODOLOGY}

This is a qualitative study of a descriptive-exploratory type in a Health Unit (HU) with Family Health Strategy (FHS) in the municipality of Curitiba, Brazil. The participants were divided in two groups. The first group had 12 people, five of those were users of homecare assistance and seven relatives. These 12 members were part of 10 different families, as one person in eight families and two people (user and relative) in two families.

The criteria of inclusion in this group were: be a relative or user of homecare service for at least six months; accept to participate voluntarily of this study; sign the Free and Clear Consent Agreement. The criteria of exclusion were: be a relative or user of homecare service for less than six months and the non-compliance with the volunteer characteristic of this study.

From the second group there were 10 health professionals that executed or coordinated the homecare service of the $\mathrm{HU}$, present in the period of this study, being six nurse assistants, two nurses, a doctor and a local Sanitary Authority. Those professionals were interviewed because they have proximity with homecare and possibly know the supportive social network.

For the second group, the criteria of inclusion were: be a health professional of the studied $\mathrm{HU}$; do or coordinate homecare; accept to participate voluntarily of this study; sign the Free and Clear Consent Agreement. The professionals that did not fit the abovementioned criteria were excluded.

The data collection happened in the period from August to October 2010 through semistructured audio-recorded interviews, composed by questions referred to the identification of the participants and open questions related to the health care received and offered, the support given in terms of material, spiritual, financial and affective resources, to the people that indicated these supports and yet, to the health 
professionals, where they acquired the information to give to the families about their options of supportive social network to homecare.

For the characterization of the participating families, we divide them in gender and age of the user, number of people per domicile, average net worth, illness that required the user to look for a homecare service and the duration of homecare service. For the characterization of the health professionals, we used many variables, suche as gender, age, main academic achievement, position or tasks executed at the $\mathrm{HU}$ and time working in FHS.

For the data analysis, the used supportive networks by the families and indicated by the professionals were classified first according to the type of support: material support, caretaking support, spiritual support, financial support and affective support; later they were then reclassified as formal or informal ${ }^{(11,12)}$. After this classification, we interlaced the networks, and later we debated the data collected based on the literature of the topic.

The study followed the ethic precepts mentioned by the Resolution 196/96 of the Brazilian National Health Council and this project was also approved by the Ethics in Research Committee of the Sciences of Health Sector of Parana Federal University (protocol CEP/SD: 940.065.10.06; protocol CAAE: 0040.0.091.000-10). It also achieved favorable notion from the Ethics Committee from the Municipal Secretary of Health of Curitiba. All participants signed the Free and Clear Consent Agreement.

\section{RESULTS}

In the participating families, five users were males and other five females, averaging 72 years old. The number of people sharing the same edification was never beyond four elements and the average net worth varied from one to seven minimum-wage units. The 
reported health problems that had the majority of the users to accept homecare were the chronic ones, as cerebral vascular accident, cancer, mellitus diabetes, obstructive lung chronic illness and renal insufficiency, and the period each user received this support varied from seven to 60 months.

The group of health professionals was predominantly formed by women, aging between 31 to 60 years old and acting in FHS over five years. Three participants who were also nursing assistants also had some undergraduate background.

The data referring to the supportive social networks were organized in three categories, named as such: "Supportive social networks used by families that receive homecare service", "Supportive social networks mentioned by health professionals that perform homecare", and "Correlation between the supportive social networks used by families and those mentioned by the health professionals while homecaring".

\section{Supportive social networks used by families that receive homecare service}

A higher number of caretaking institutions mentioned by the families able to subsidize the care done at home related themselves with those providers of materials for the caretaking, which were mostly diapers, medication, hygiene supplies, general items for the execution of homecaring and locomotion products, such as canes, wheelchairs and crutches.

The care to the user in most families was performed by family members themselves and reveals a certain support in caring. Health professionals sometimes guided these relatives. The spiritual care was the most mentioned, as it was present in 8 out of the 10 participating families and the majority came from religious institutions. One of the relatives related televised shows as a format of this type of care.

Referring to the financial support, six out of ten participating families affirmed that they

NASCIMENTO JD, LACERDA MR, KALINOWSKI LC, FAVERO L. Supportive social networks to homecare: a descriptive exploratory study. Online braz. J. nurs. (Online); 10(3) set-dez. 2011. 
do not have any, however after analyzing the interviews, it was then discovered that the families consider as financial support only the one received in cash only and not other variations, as food baskets (Brazilian version of US' food stamps) and support of the Brazilian Public Social Security Fund. The affective support was little expressive, broadening only the people of their own family group, such as sons, wives and grandsons.

When the support was then reclassified as formal or informal, it was observed that the informal support came from individuals usually close to the residence, as relatives (especially sons and wives), neighbors and nearby residents that helped either in the execution of the caretaking or the provision of goods to the user.

It was olso found that in informal supportive social networks the presence of laborers of the HU yet linked with a formal supportive social network, offering support able to transform the once formal situation to an informal one, when acting individually and then, getting closer to the user.

In the formal support, as to say, the one that comes from recognized institutions, it was perceived that the majority of the mentioned support was given by religious institutions, like churches and self-empowerment groups. It was also observed that some public organisms, like the municipality, the Mobile Treatment of Emergency Service (SAMU, in Portuguese) and the Social Action Foundation (FAS, in Portuguese). It is important to call attention that two out of the participating ten families, with exception of the support given by the $\mathrm{HU}$, reported they do not receive any other formal support.

\section{Supportive social networks indicated by health professionals that perform homecare}

As a reference to material support, the health professionals indicated the private 
companies, the Non-Governmental Organizations (NGOs), the foundations, among others. We bring to light the importance of the $\mathrm{HU}$ as provider of this type of support, as it supplies material to make homecare possible. There was a hope, however, that the health professionals pointed to it as the most important source of material support for home caring, but it was only mentioned by four out of 10 interviewed professionals.

It was also noticed the participation of religious institutions supplying the materials for home caring, such as local companies, on which used fiscal incentives to donate.

When questioned about the indication of spiritual support, six out of 10 participants affirmed they do not get involved in such matter. On the other hand, it was possible to see that some professionals mention religious groups existing in the community and are concerned in not indicating one specific faith.

The financial support indicated was especially from governmental institutions, suchas the FAS, the Social Assistance Reference Center (CRAS, in Portuguese), the municipality and the religious institutions. The orientation of this type of support most observed in interviews mentioned retirement, either because of health issues or advanced age.

The indication of the professionals related to affective support constituted basically of a meeting with the whole family group to identify a main caretaker that can assist the health professionals during the execution and maintenance of homecare. Some public protective institutions were also referred to, such as the Public Ministry and the Seniors' Council, when the user was a senior, particularly those who are neglected or suffer maltreatment. For these users, there is a need of State intervention so homecare is well established.

We should also highlight that the support in caretaking was not among the mentioned supportive social networks by the professionals.

In relation to the informal support, the participating professionals mentioned a few, limiting themselves to the indication of religious people, family members and neighbors of the users, colleagues and other personnel of the HU.

In formal relationships, some private companies, public institutions such as the 
municipality and its departments and yet the FAS, CRAS, the Paranaean Rehabilitation Association (APR, in Portuguese) and the HU were mentioned. Rights Defense Institutions were also mentioned, like the Public Ministry and the Seniors' Council, besides some religious groups, like the Palazoro Institute, the Home of the Girls and some churches.

\section{Correlation between the supportive social networks used by the families and those mentioned by the health professionals while homecaring}

When analyzing the speech of the two participant groups, we realized that in the families group the social networks were made, in their majority, of individuals. The health professionals, on the other hand, used to suggest institutions to search for aid.

Yet, in the interlace of speeches it was possible to visualize that the spiritual support is quite important for the families that have a member who needs homecare, despite the fact health professionals do not mention a significative support from this type.

For the majority of the health professionals, the HU has its attributions and attends the necessities of the users and families that require homecare, but, in fact, what can be heard from the families was not the acknowledgement of these functions, once there were some flaws cited that were not from the competencies of the professionals there allocated.

Besides that, other health professionals, not members of the nursing team, recognize the identification and indication of the supportive social networks as a specific attribution of the nurse.

\section{DISCUSSION}

NASCIMENTO JD, LACERDA MR, KALINOWSKI LC, FAVERO L. Supportive social networks to homecare: a descriptive exploratory study. Online braz. J. nurs. (Online); 10(3) set-dez. 2011. 
In the characterization of participant families, related to the age of the users of this study, there was a predominance of seniors, those that, in Brazil, in accordance to Law 8.842 , Article 2 Item I, are 60 or more years old ${ }^{6}$. Besides that, the process of ageing brings, among other alterations, changes in the morbid-mortality pattern, with the rise of, not only the incidence, but also the prevalence of chronic diseases ${ }^{13}$, a problem which also affected the participants of this study.

In relation to the number of people sharing the same housing unit, we must cite the living among them facilitates monitoring behavior in according to their patologies ${ }^{14}$, and then, as many people are there in the family, higher is their shared living, possibly improving their health conditions.

In the health professionals interviewed group, it was seen that the time of action of the FHS is over five years, a fact to be stated once more time dedicated to this labor can proportionate to the professional the recognition of the necessity to count on the supportive social networks to develop homecare.

Referring to the supportive social networks used by the families who receive homecare, it was noted the importance given to spiritual care, once it works as a "shock absorber" for the caretakers in relation to the harmful effects to health, helps to elaborate new senses and meanings for life and supports the people when facing adverse situations ${ }^{15}$.

The restrict number of affect support in the families can be justified by the fact that, while impaired, the individual does not participate or has reduced participation in social activities, besides reducing also the initiatives of exchanges with other people, resulting in a reduction of interaction with other people ${ }^{16}$.

Many individuals, especially relatives as sons and wife, were mentioned as donors of informal care to the families, able to give aid and care. This reinforces the idea that sons and wives share the task of caring, imbued of affective feelings, duties and obligations, culturally influenced by values and believes ${ }^{(4)}$.

On the formal support, families named some institutions, qualified as formal as the 
possess a systematization of a support format and do not aim to only a specific individual, but to the whole population ${ }^{(16)}$.

The fact that two out of 10 participating families report not to receive any other formal support, besides the one from the $\mathrm{HU}$, is a preoccupation for the life style they possess, because the non-existence of such networks can contribute negatively for the development of homecare treatments.

And referring to the supportive social networks mentioned by the health professionals that acted as home caretakers, we could then see that the supply of the needed material for homecaring comes mostly from religious institutions and local private companies. This type of support enlaces the access of individuals to services or to material resources, which includes, for example, support in cash or lending of equipment ${ }^{(12)}$.

The majority of the professionals reported that they do not mention spiritual support and this can be justified by the question that was part of the study which had a higher number of nurse assistants, and according to the Law $7.498 / 86^{17}$, which disposes about the exercise of Nursing in Brazil, it is deprived from the nurse the planning, the organization, the coordination, the execution and the evaluation of Nursing assistance services, besides from the prescription of this assistance and yet as a member of a health team to participate in programs and activities that aim the improvement of the health condition of an individual, of the family and the population in general.

Although a study conducted with health professionals demonstrated that the same to believe in a certain divine protection and recognize religiosity as something important and as means of comfort for the patient and his relatives to go through the illness state ${ }^{(18)}$. In this sense, the importance of spiritual support indicated by the nurse is highlighted, once religiosity is a basic human necessity that needs to be contemplated in the care given by this professional.

The support in caretaking did not appeared among the supportive social networks mentioned by the professionals, and because of that it is believed that the lack of an indication of this sort would be by the fact the responsible people for the caretaking done 
at home are the relatives and the HU professionals, without a clear indication from other sectors, services, groups or institutions.

In the formal relations a research emphasizes that, differently from the discourses of the families, the health professionals indicated volunteer associations, and these determined the degree of organization and activity of the civil society ${ }^{14}$.

When correlating, the supportive social networks pointed out by the two participant groups, it was noted in the literature that it is the health professional's duty to indicate those named networks to the families so they are not overwhelmed, helpless or withour pertinent information, which all can interfere directly with the quality of life of the caretaker and of the person being taken care of ${ }^{(4)}$.

Concerning to the Nursing, it is important to mention the details related to homecare, which need to be learned during the undergraduate course. This step will provide future professionals with the ability to really transpose the barrier of caring based on a biomedical model, which is yet vastly used ${ }^{(19)}$.

When knowing and pointing the available the supportive social networks available, nurses can facilitate the users while dealing the difficulties related to the necessities of homecare, besides the possibility to use such networks as instruments to maximize their work.

Such condition is important, once the final objective - healthcare - in its social expression is more than the treatment of the symptoms, but the reinsertion of the individual in the society, because the person while integrated has more chances to live longer and will eventually have more resources to face and/or recover from physical, psychological and social suffering that affect his general health ${ }^{(20)}$.

\section{FINAL CONSIDERATIONS}

The supportive social networks are fundamentals to attend the necessities of the individuals and the community, especially in the imminence of homecare. With this, it is 
important the participation of many sectors and organizations, as the process of maintenance of health and prevention of illnesses through a historical-social construction and of the living situations.

With this study it was possible to identify different networks used by the families and indicated by the health professionals in homecare, which can contribute for the performance of these workers, especially the nurses. With a classification of these networks it was possible to identify the differences between the networks used by the families that had homecare service provided to them and those other networks mentioned by the health professionals, as the study of those networks allows the mapping of the relations between individuals or groups.

The fact of knowing these supportive social networks enough to materialize them, or simply to talk about them, consists on the first step for the nurse to assess and use them.

It is necessary that the nurse guides the family so that they restructure themselves and divide among themselves the tasks related to homecare, also using the supportive social networks. Within this context, we highlight the importance of the incentive in capacitated human resources to attend the user that needs homecare, allied with the academic instruction and correct indication of supportive social networks, aiming to alleviate the overload to the families.

Within the limitations found to perform this study, it is central to call attention to the impossibility of a deeper knowledge about the specific actions performed by each network. This way, there is a vacancy, which is indicated to studies that want to explore this topic. As a conclusion, we suggest the articulation among the health professionals, mainly the nurse, with other local institutions for the creation of supportive social networks that can improve treatment and proportionate a health positive impact in users and caretakers.

\section{REFERENCES}

NASCIMENTO JD, LACERDA MR, KALINOWSKI LC, FAVERO L. Supportive social networks to homecare: a descriptive exploratory study. Online braz. J. nurs. (Online); 10(3) set-dez. 2011. 
1. Feuerwerker LCM, Merhy EE. A contribuição da atenção domiciliar para a configuração de redes substitutivas de saúde: desinstitucionalização e transformação de práticas. Rev Panam Salud Publica 2008; 24(3): 180-188.

2. Hirschfeld MJ, Oguisso T. Visäo panorâmica da saúde no mundo e a inserção do home care. Rev Bras Enferm 2002; 55(4): 452-459.

3. Kerber NPC, Kirchhof ALC, Cezar-Vaz MR. Considerações sobre a atenção domiciliária e suas aproximações com o mundo do trabalho na saúde. Cad Saude Publica 2008; 24(3): 485-493.

4. Nardi EFR, Oliveira MLF. Conhecendo o apoio social ao cuidador familiar do idoso dependente. Rev Gauch Enferm 2008; 29(1): 47-53.

5. Brasil. Ministério da Saúde. Lei $n^{\circ} 10.741$, de $1^{\circ}$ de outubro de 2003. Dispõe sobre o Estatuto do Idoso e dá outras providências. Brasília: Ministério da Saúde; 2003.

6. Brasil. Ministério da Saúde. Lei $n^{\circ}$ 8.842, de 4 de janeiro de 1994. Dispõe sobre a política nacional do idoso, cria o Conselho Nacional do Idoso e dá outras providências. Brasília: Ministério da Saúde; 1994.

7. Pedro ICS, Rocha SMM, Nascimento LC. Apoio e rede social em enfermagem familiar: revendo conceitos. Rev Latino-Am Enferm [Internet]. 2008 [citado em 2011 nov 02]; 16(2): 324-327. Disponível em: http://www.scielo.br/pdf/rlae/v16n2/pt 24.pdf

8. Catafesta F, Lacerda MR. Skills of nurses needed for the development of home care: reflection. Online Braz J Nurs [Internet]. 2008 [citado em 2011 nov 02]; 7(2). Disponível em:

http://www.objnursing.uff.br//index.php/nursing/article/view/j.16764285.2008.1302/345

9. Valla VV. Educação popular, saúde comunitária e apoio social numa conjuntura de globalização. Cad Saude Publica 1999; 15(Supl 2): 7-14.

10. Gomes IM, Lacerda MR. Correlations between social support and the home nursing: integrative review. Online Braz ] Nurs [Internet]. 2010 [citado em 2011 nov 02]; 9(1). Disponível em:

NASCIMENTO JD, LACERDA MR, KALINOWSKI LC, FAVERO L. Supportive social networks to homecare: a descriptive exploratory study. Online braz. J. nurs. (Online); 10(3) set-dez. 2011. 
http://www.objnursing.uff.br/index.php/nursing/article/view/j.16764285.2010.2876/658

11. Nóbrega VM, Collet N, Silva KL, Coutinho SED. Rede e apoio social das famílias de crianças em condição crônica. Rev Eletr Enf [Internet]. 2010 [citado em 2011 nov 02]; 12(3):431-440. Disponível em: http://www.fen.ufg.br/revista/v12/n3/v12n3a03.htm

12. Pinto JLG, Garcia ACO, Bocchi SCM, Carvalhaes MABL. Características do apoio social oferecido a idosos de área rural assistida pelo PSF. Cienc Saude Colet 2006; 11 (3): 753764. Disponível em: http://www.scielo.br/pdf/csc/v11n3/30990.pdf

13. Bastos CC, Lemos ND, Mello AN. Perfil clínico-demográfico dos pacientes inseridos em um programa de assistência domiciliária no município de São Paulo. Rev Kairos 2007; 10(2): 205-224.

14. Andrade GRB, Vaitsman J. Apoio social e redes: conectando solidariedade e saúde. Cienc Saude Colet 2002; 7(4): 925-934.

15. Marques AKMC, Landim FLP, Collares PM, Mesquita RB. Apoio social na experiência do familiar cuidador. Cienc Saude Colet 2011; 16(Supl 1): 945-955.

16. Landin FLP, Comaru JL, Mesquita RB, Collares PM. Redes sociais informais de uma comunidade da periferia de Fortaleza. Cogitare Enferm 2006; 11(1): 16-23.

17. Brasil. Decreto no. 94.406, de 8 de junho de 1987. Regulamenta a Lei no. 7.498 de 25 de junho de 1986. Dispõe sobre o Exercício da Enfermagem e dá outras providências. Diário Oficial da República Federativa do Brasil, Poder Executivo, Brasília, p. 8853-8855, jun. 1987.

18. Espíndula JA, Valle ERM, Bello AA. Religião e espiritualidade: um olhar de profissionais de saúde. Rev Latino-Am Enferm [Internet]. 2010 [citado em 2011 nov 02]; 18(6): 1229-1236. Disponível em: http://www.scielo.br/pdf/rlae/v18n6/pt 25.pdf

19. Hermann AP, Méier MJ, Wall ML, Bernardino E, Lacerda MR. A formação para o cuidado domiciliar: aspectos encontrados na produção científica da enfermagem brasileira. Cogitare Enferm 2009; 14(4): 748-754.

20. Souza J, Kantorski LP. A rede social de indivíduos sob tratamento em um CAPS ad: o ecomapa como recurso. Rev Esc Enferm USP 2009; 43(2): 373-383.

NASCIMENTO JD, LACERDA MR, KALINOWSKI LC, FAVERO L. Supportive social networks to homecare: a descriptive exploratory study. Online braz. J. nurs. (Online); 10(3) set-dez. 2011. 
NASCIMENTO JD, LACERDA MR, KALINOWSKI LC, FAVERO L. Supportive social networks to homecare: a descriptive exploratory study. Online braz. J. nurs. (Online); 10(3) set-dez. 2011. 